\title{
MEASURING THE CONCENTRATION OF RADON GAS IN THE OPERATION UNITE OF THE DOURA REFINERY
}

Hayder $\mathrm{S}^{1}$. Hussain, Bushra Ahmed ${ }^{2}$ and Mustafa karam ${ }^{3}$

Abstract : The concentration of radon indoor and outdoor have been measured by RAD - 7 dives, where radon concentrations in operational units of the Doura refinery in the indoor range from $6.21 \pm 30 \mathrm{~Bq} / \mathrm{m}^{3}$ to $12.4 \pm 33 \mathrm{~Bq} / \mathrm{m}^{3}$ with an average value of $5.31 \pm 18 \mathrm{~Bq} / \mathrm{m}^{3}$. In open spaces ranging from $6.21 \pm 30 \mathrm{~Bq} / \mathrm{m}^{3}$ to (N D) with an average value of $0.44 \pm 2.1 \mathrm{~Bq} / \mathrm{m}^{3}$. The result shows that the average radon levels are acceptable. Also, the estimation of annual effective dose (AED) of ${ }^{222} \mathrm{Rn}$ concentration, with the average indoor air (0.1) and outdoor air (0.007), and calculation Working Level values and Working Level Month of ${ }^{222} \mathrm{Rn}$ concentrations, show that all results are within acceptable limits.

Key words (Rad-7 / ED / WL / WLM)

\section{INTRODUCTION}

Radon is a naturally occurring radioactive, odorless, col orless gas that is conti nuousl y rel eased by natural sources, such as geol ogi cal formations in soil and construction materials. Radon and its daughters are forned during the radi oacti ve decays of urani umand thori um in the earth' s crust, to l ead, of which the I atter is the stable product of the decay processes. The various half-lives of the radio nucl ides are very i nportant in determining the rel ative contributions of the decay series to bronchial dose. The hal f-I ife of ${ }^{222} \mathrm{Rn}$ is 3. 8. It has four short-l i ved decay products: ${ }^{218} \mathrm{Po} \quad(3.05 \mathrm{mnn}),{ }^{214} \mathrm{~Pb} \quad(26.8 \mathrm{~min}),{ }^{214} \mathrm{Bi} \quad(19.9 \mathrm{~min})$, and ${ }^{214} \mathrm{Po}$ $(164 \mu \mathrm{s})$. Both pol oni umi sotopes are al pha-enntters. The rel ati vel y short hal $\mathrm{f}-\mathrm{I}$ i fe of ${ }^{220} \mathrm{Rn}(55.6 \mathrm{~s})$ means that it does not have noch ti ne to travel fromits production si te to the i mmedi ate envi ronnent of human bei ngs. The rel ati vel y I ong hal f-I i fe of one of its decay products, ${ }^{212} \mathrm{~Pb}(10.6 \mathrm{~h})$, al l ous this isotope time to deposit on surfaces or migrate away fromits source before producing the inportant al pha enitter ${ }^{212} \mathrm{Bi}(60.6 \mathrm{~min})$. The rel ati ve concentrati ons of the vari ous radi onucl i des in the decay series are al so strongly affected by dynanic processes, incl uding the attachnent of the decay products to aerosol particl es and their subsequent deposition

${ }^{1}$ Baghdad University - College of science Baghdad - Iraq

${ }^{2}$ Ministry of Health and Environment - Radiation protection center Baghdad - Iraq

${ }^{3}$ Ministry of Health and Environment - Radiation protection center Baghdad - Iraq 
on roomsurfaces or the ground as well as ai $r$ novenent in general. The fracti on of radon progeny in an ultrafine node $(0.5-2 \mathrm{~nm}$, not attached to anbi ent aerosol particles, is known as the unattached fracti on [1].

The i nhal at i on of radon ${ }^{222} \mathrm{Rn}$ and i ts radi oacti ve daughters, even for peopl e exposed to I ow radon l evel s that may be found in resi denti al buil di ngs [2], i ncreases the chance of devel opi ng I ung cancer [3]. When i nhal ed, radon particles carryi ng daughters enter and stick onto the bronchi al ai $r$ passages, i rradi ating and danagi ng the surrounding cells. Based on nati onal and worldwi de i nvestigations, several agenci es have concl uded that radon is a known cancer causi ng agent in humans and is the second nost common cause of I ung, ski n, and l eukemia cancers after snoki ng [4]. Radon enters the body systemduring i nhal ati on, which results in an increase in the exposure dose that can result in the devel opnent of I ung cancer. ${ }^{222} \mathrm{Rn}$ and its progeny in ai $r$ are the nost i mportant contributors to human exposure from al I natural radi ati on sources [5].

\section{A. Dose Estimation}

From the measured indoor and outdoor radon concentrations, annual effective doses have been calculated using equation [6].

$\mathrm{E}=\mathrm{C} \times \mathrm{F} \times \mathrm{H} \times \mathrm{T} \times \mathrm{D}$

where $\mathrm{C}$ is the ${ }^{222} \mathrm{Rn}$ concentration $\left(\mathrm{Bq} / \mathrm{m}^{3}\right), \mathrm{F}$ is equilibrium factor $(0.4), \mathrm{H}$ is the occupancy factor $(0.8$ was estimated for this work), $\mathrm{T}$ is hours in a year $(8760 \mathrm{~h} / \mathrm{y})$ and $\mathrm{D}$ is the dose conversion factor $\left(9.0 \times 10^{-}\right.$ $\left.{ }^{6} \mathrm{mSv} / \mathrm{Bq} / \mathrm{m}^{3} \mathrm{~h}\right)$.

\section{B. Calculation the (EEC) in $\mathrm{Bq} / \mathrm{m}^{3}$ and exposure (E) to ${ }^{222} \mathrm{Rn}$ concentrations in (WL and WLM) in operational units of the Doura refinery.}

The equilibrium equivalent ${ }^{222} \mathrm{Rn}$ concentration (EEC) is calculated by using equation.

$\mathrm{F}=\frac{\mathrm{EEC}}{\mathrm{CRn}}$

Exposure to ${ }^{222} \mathrm{Rn}$ concentrations, in terms of working level (WL) and working level month (WLM), in operational units of the Doura refinery also have been calculated using equations respectively [6].

$\mathrm{WL}=\mathrm{EEC} \times(0.27 / 1000)$

$\mathrm{WLM}=\mathrm{WL} \times(8760 / 170)$

\section{EXPERIMENTAL WORK}

In the interior of the measurement instrument RAD-7 from Durridge Company we find a hemisphere with a silicon solid-state detector. A representation of the measurement chamber with the detector is shown in Figures 1 and 2 [7]. Through the filter the sample air is sucked in by the pump and reaches the detector chamber. There a high voltage of 2000 to $2500 \mathrm{~V}$ between the detector and the hemisphere accelerates the positively ionized particles towards the detector. If a radon nucleus decays in the chamber into a positively ionized ${ }^{218} \mathrm{Po}$ this particle will be accelerated towards the detector. On the surface of the detector the short lived ${ }^{218}$ Po decays and the $(\boldsymbol{\alpha})$ particle with a characteristic energy is emitted to the detector. The detector produces a signal with (50) per cent probability. This signal is intensified electronically and transformed into a digital signal. The microprocessor stores the energy level of the signal and produces the spectrum. 


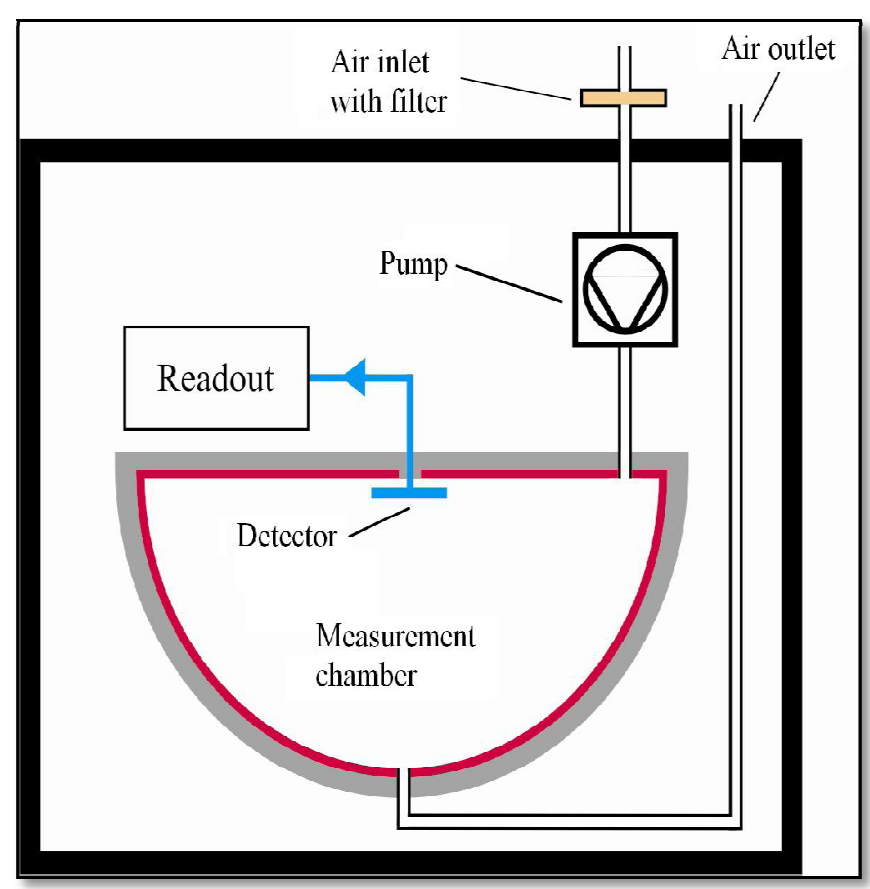

Figure 1. A diagram showing the measurement chamber of the RAD -7.

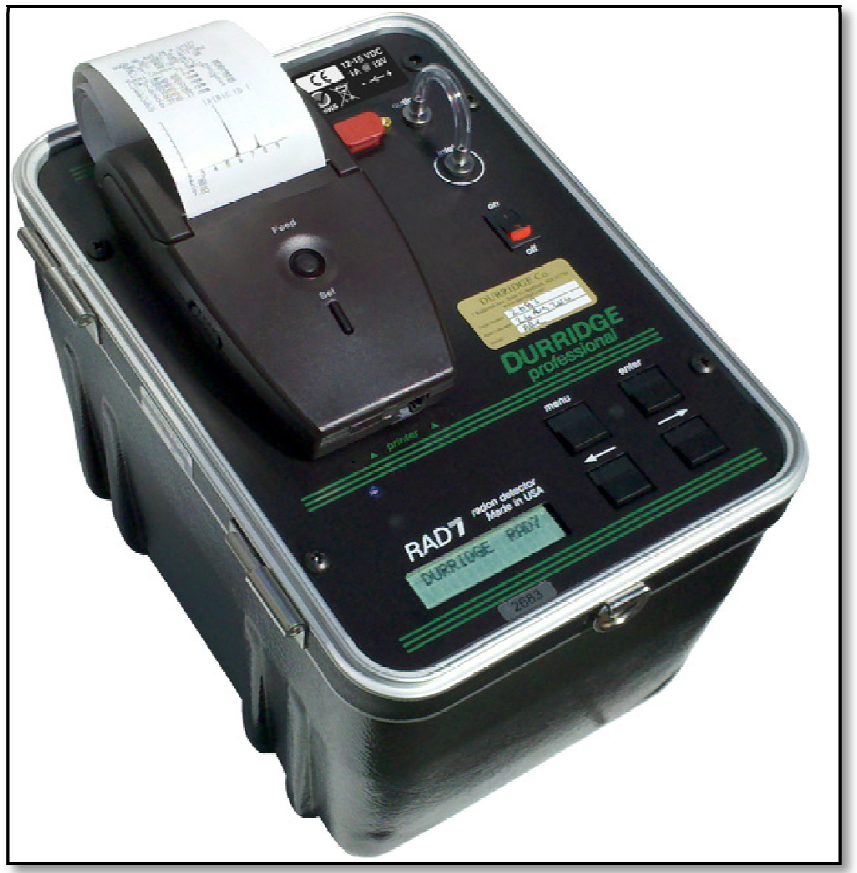

Figure 2. RAD - 7 electronic radon detectors

\section{RESULTS AND DISCUSSION}

The concentration of radon indoor and outdoor by RAD-7 detector has been measured, where radon concentrations in operational units of the Doura refinery in the indoor range from $6.21 \pm 30 \mathrm{~Bq} / \mathrm{m}^{3}$ to $12.4 \pm 33 \mathrm{~Bq} / \mathrm{m}^{3}$ with an average value of $5.31 \pm 18 \mathrm{~Bq} / \mathrm{m}^{3}$. Outdoor, concentrations of Radon gas range from $6.21 \pm 30 \mathrm{~Bq} / \mathrm{m}^{3}$ to $(\mathrm{N} \mathrm{D})$ with an average value of $0.44 \pm 2.1 \mathrm{~Bq} / \mathrm{m}^{3}$ as indicated in Table1.

The minimum value of indoor air has been observed in the unit of (Ro), as there is good ventilation at the site being alongside Tigress River, whereas the maximum value of indoor air has been observed in department of stores, as this department is located on the ground floor, with a large area, where there is no enough ventilation.

It is also noted that the minimum value of the outdoor air has been observed in the unit of (Ro), as there is good ventilation at the site being alongside Tigress River, whereas the maximum value of the outdoor air 
Measuring The Concentration Of Radon Gas In The Operation Unite Of The Doura Refinery 48

has been observed in Improving Gasoline Unit (2) because it is located between the Improving Gasoline Unit (1) and the administration building, which affects the ventilation.

\begin{tabular}{|l|l|l|}
\hline & Name of Departments & Radon concentrations $\left(\mathrm{Bq} / \mathrm{m}^{3}\right)$ \\
\hline
\end{tabular}




\begin{tabular}{|c|c|c|c|}
\hline No. & and Units & Indoor & outdoor \\
\hline A1 & Refining unit 1 & $6.21 \pm 30$ & N D \\
\hline $\mathrm{A} 2$ & Refining unit 2 & $12.4 \pm 33$ & $\mathrm{ND}$ \\
\hline A3 & Refining unit 3 & N D & N D \\
\hline A4 & improving gasoline Unit 1 & N D & N D \\
\hline A5 & improving gasoline Unit 2 & $12.4 \pm 33.9$ & $6.21 \pm 30$ \\
\hline A6 & RO Unit & $\mathrm{ND}$ & $\mathrm{ND}$ \\
\hline A7 & $\begin{array}{l}\text { Department of Energy } \\
\text { (crypt water pumps) }\end{array}$ & $6.21 \pm 30$ & N D \\
\hline A8 & Department stores & $12.4 \pm 33$ & N D \\
\hline A9 & Oil Department 3 & N D & N D \\
\hline A10 & Oil Department 2 & $12.4 \pm 33$ & N D \\
\hline A11 & Oil Department 1 & N D & N D \\
\hline A12 & Water Treatment Department & N D & N D \\
\hline A13 & Laboratory Heavy Water Treatment & $6.21 \pm 30$ & N D \\
\hline A14 & Department pumping and Storage & $6.21 \pm 30$ & N D \\
\hline & Average & $5.31 \pm 18$ & $0.44 \pm 2.1$ \\
\hline
\end{tabular}

Table-1 Radon concentrations in operational units of the Doura refinery. 


\section{The \\ Rado \\ n \\ Conce \\ ntrati \\ ons \\ (Bq/ \\ m)}

\begin{tabular}{|c|c|c|c|}
\hline Samples & EEC & WL & WLM \\
\hline
\end{tabular}

Figure 3. Summary of radon concentration value in $\mathbf{B q} / \mathbf{m}^{3}$ in operational units of the Doura refinery.

\section{A. Calculation of equilibrium equivalent concentration, working Level and working level month of ${ }^{222} \mathrm{Rn}$ concentrations in operational units of the Doura refinery.}

The equilibrium equivalent ${ }^{222} \mathrm{Rn}$ concentration (EEC).In addition, exposure to ${ }^{222} \mathrm{Rn}$ concentrations, in terms of working level (WL) and working level month (WLM), in operational units of the Doura refinery

The calculated results for equilibrium equivalent ${ }^{222} \mathrm{Rn}$ concentration and ${ }^{222} \mathrm{Rn}$ exposures in terms of WL and WLM for indoor air and outdoor air in operational units of the Doura refinery were within allowable limits is as indicated in Table 2 [8]. Figure 1 and $2{ }^{222} \mathrm{Rn}$ exposure in WL and WLM in operational units of the Doura refinery . 


\begin{tabular}{|c|c|c|c|c|c|c|}
\hline & indoor & outdoor & indoor & outdoor & indoor & outdoor \\
\hline A1 & 3.105 & 0 & $8.3 \times 10^{-4}$ & 0 & $4.3 \times 10^{-2}$ & 0 \\
\hline $\mathrm{A} 2$ & 6.2 & 0 & $1.6 \times 10^{-3}$ & 0 & $8.6 \times 10^{-2}$ & 0 \\
\hline A3 & 0 & 0 & 0 & 0 & 0 & 0 \\
\hline A4 & 0 & 0 & 0 & 0 & 0 & 0 \\
\hline A5 & 6.2 & 3.105 & $1.6 \times 10^{-3}$ & $8.3 \times 10^{-4}$ & $8.6 \times 10^{-2}$ & $4.3 \times 10^{-2}$ \\
\hline A6 & 0 & 0 & 0 & 0 & 0 & 0 \\
\hline A7 & 3.105 & 0 & $8.3 \times 10^{-4}$ & 0 & $4.3 \times 10^{-2}$ & 0 \\
\hline A8 & 6.2 & 0 & $1.6 \times 10^{-3}$ & 0 & $8.6 \times 10^{-2}$ & 0 \\
\hline A9 & 0 & 0 & 0 & 0 & 0 & 0 \\
\hline A10 & 6.2 & 0 & $1.6 \times 10^{-3}$ & 0 & $8.6 \times 10^{-2}$ & 0 \\
\hline A11 & 0 & 0 & 0 & 0 & 0 & 0 \\
\hline A12 & 0 & 0 & 0 & 0 & 0 & 0 \\
\hline A13 & 3.105 & 0 & $8.3 \times 10^{-4}$ & 0 & $4.3 \times 10^{-2}$ & 0 \\
\hline A14 & 3.105 & 0 & $8.3 \times 10^{-4}$ & 0 & $4.3 \times 10^{-2}$ & 0 \\
\hline \multicolumn{3}{|c|}{ Average } & $7.1 \times 10^{-4}$ & $5.9 \times 10^{-5}$ & $3.6 \times 10^{-2}$ & $3 \times 10^{-3}$ \\
\hline
\end{tabular}

Table-2 the calculated values of (EEC) in $\mathrm{Bq} / \mathrm{m}^{3}$, and exposure (E) to ${ }^{222} \mathrm{Rn}$ concentrations in (WL and WLM) in operational units of the Doura refinery.

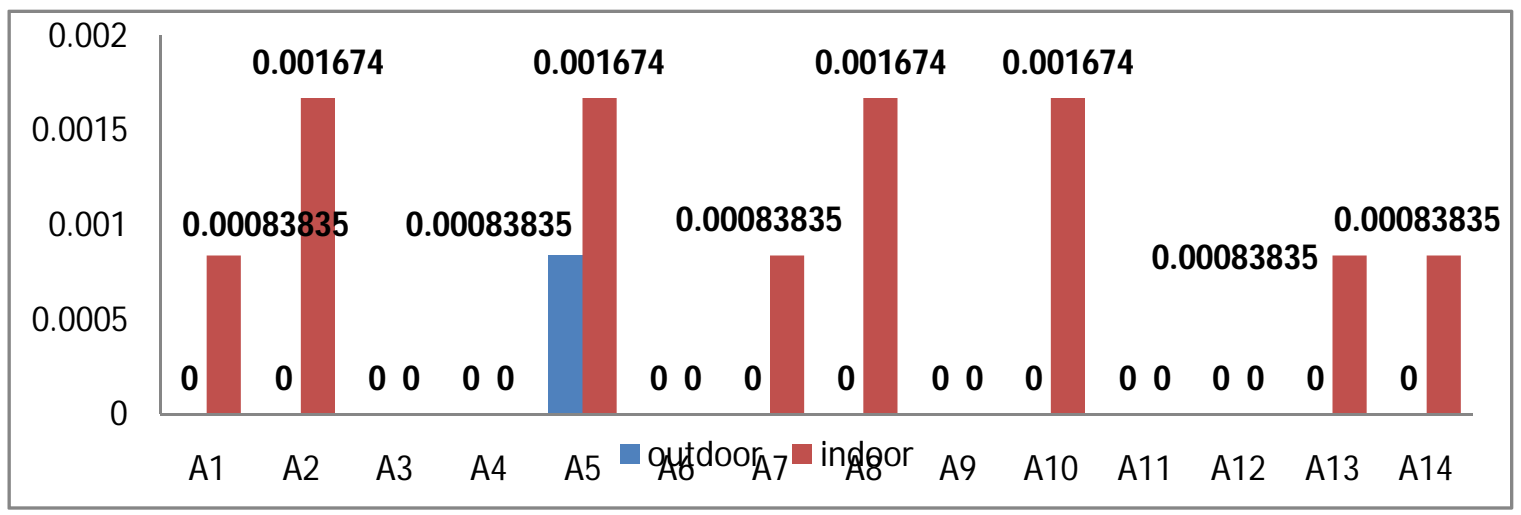

Figure $4 .{ }^{222} \mathrm{Rn}$ exposure in WL in operational units of the Doura refinery

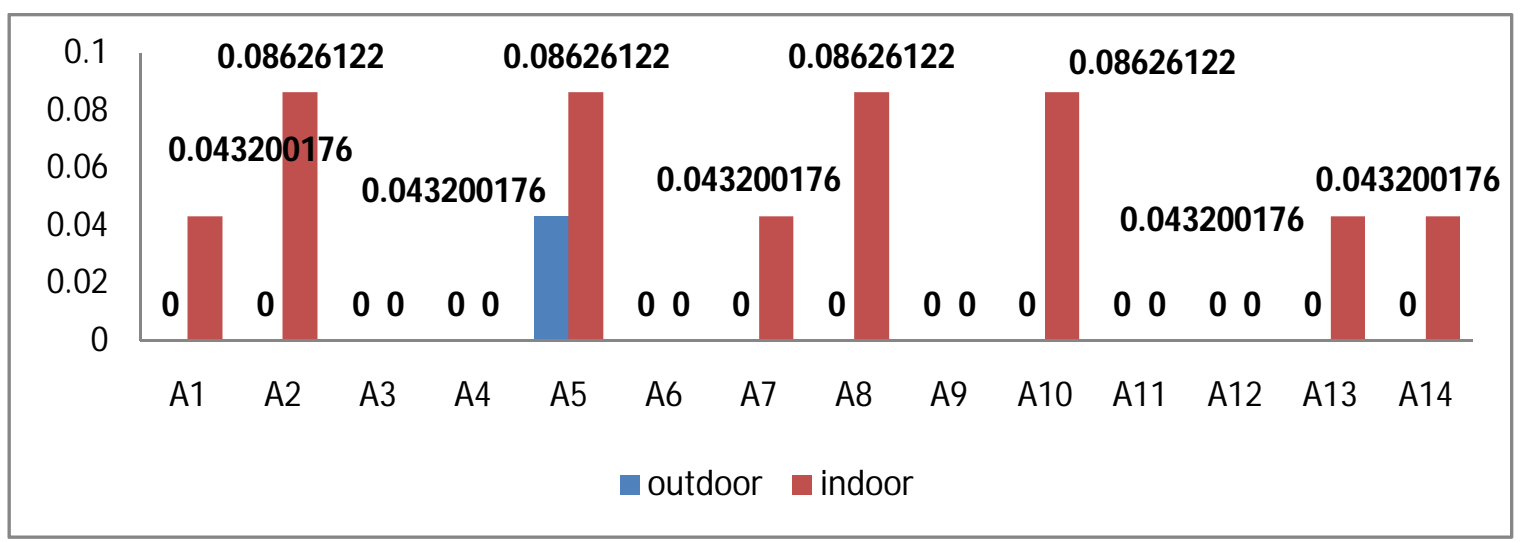

Figure $5 .{ }^{222} \mathrm{Rn}$ exposure in WLM in operational units of the Doura refinery

\section{B. The Estimation of Annual Effective Dose of ${ }^{222} \mathrm{Rn}$ Concentrations in operational units of the Doura refinery.}


Measuring The Concentration Of Radon Gas In The Operation Unite Of The Doura Refinery 52 The estimation of annual effective dose (AED) of ${ }^{222} \mathrm{Rn}$ concentration in operational units of the Doura refinery were measured as indicated in Tables: 3 where all results were within the allowable limits.

Tables -3 the annual effective dose and of ${ }^{222} \mathrm{Rn}$ Concentrations in operational units of the Doura refinery.

\begin{tabular}{|c|c|c|c|c|}
\hline NO & $\mathrm{C}\left(\mathrm{Bq} / \mathrm{m}^{3}\right)$ indoor & $\begin{array}{c}\text { annual effective doses } \\
\mathrm{mSv} / \mathrm{y}\end{array}$ & $\mathrm{C}\left(\mathrm{Bq} / \mathrm{m}^{3}\right)$ outdoor & $\begin{array}{c}\text { annual effective doses } \\
\mathrm{mSv} / \mathrm{y}\end{array}$ \\
\hline A1 & $6.21 \pm 30$ & 0.1 & ND & 0 \\
\hline A2 & $12.4 \pm 33$ & 0.3 & ND & 0 \\
\hline $\mathbf{A 3}$ & ND & 0 & N D & 0 \\
\hline A4 & N D & 0 & ND & 0 \\
\hline A5 & $12.4 \pm 33.9$ & 0.3 & $6.21 \pm 30$ & 0.1 \\
\hline A6 & ND & 0 & ND & 0 \\
\hline A7 & $6.21 \pm 30$ & 0.1 & N D & 0 \\
\hline A8 & $12.4 \pm 33$ & 0.3 & N D & 0 \\
\hline A9 & N D & 0 & N D & 0 \\
\hline A10 & $12.4 \pm 33$ & 0.1 & N D & 0 \\
\hline A11 & ND & 0 & N D & 0 \\
\hline $\mathbf{A 1 2}$ & ND & 0 & N D & 0 \\
\hline A13 & $6.21 \pm 30$ & 0.1 & N D & 0 \\
\hline A14 & $6.21 \pm 30$ & 0.1 & N D & 0 \\
\hline Average & $5.31 \pm 18$ & 0.1 & $0.44 \pm 2.1$ & 0.007 \\
\hline
\end{tabular}

\begin{tabular}{|c|c|c|c|c|}
\hline $\mathbf{N O}$ & $\mathbf{C}\left(\mathbf{B q} / \mathbf{m}^{3}\right)$ indoor & $\begin{array}{c}\text { annual effective doses } \\
\mathbf{m S v} / \mathbf{y}\end{array}$ & $\mathbf{C}\left(\mathbf{B q} / \mathbf{m}^{\mathbf{3}}\right)$ outdoor & $\begin{array}{c}\text { annual effective doses } \\
\mathbf{m S v} / \mathbf{y}\end{array}$ \\
\hline $\mathbf{A 1}$ & $6.21 \pm 30$ & 0.1 & $\mathrm{~N} \mathrm{D}$ & 0 \\
\hline $\mathbf{A 2}$ & $12.4 \pm 33$ & 0.3 & $\mathrm{~N} \mathrm{D}$ & 0 \\
\hline $\mathbf{A 3}$ & $\mathrm{N} \mathrm{D}$ & 0 & $\mathrm{~N} \mathrm{D}$ & 0 \\
\hline $\mathbf{A 4}$ & $\mathrm{N} \mathrm{D}$ & 0.3 & $6.21 \pm 30$ & 0.1 \\
\hline $\mathbf{A 5}$ & $12.4 \pm 33.9$ & 0 & $\mathrm{~N} \mathrm{D}$ & 0 \\
\hline $\mathbf{A 6}$ & $\mathrm{N} \mathrm{D}$ & 0.1 & $\mathrm{~N} \mathrm{D}$ & 0 \\
\hline $\mathbf{A 7}$ & $6.21 \pm 30$ & 0.3 & $\mathrm{~N} \mathrm{D}$ & 0 \\
\hline $\mathbf{A 8}$ & $12.4 \pm 33$ & 0 & $\mathrm{~N} \mathrm{D}$ & 0 \\
\hline $\mathbf{A 9}$ & $\mathrm{N} \mathrm{D}$ & 0.1 & $\mathrm{~N} \mathrm{D}$ & 0 \\
\hline $\mathbf{A 1 0}$ & $12.4 \pm 33$ & 0 & $\mathrm{~N} \mathrm{D}$ & 0 \\
\hline $\mathbf{A 1 1}$ & $\mathrm{N} \mathrm{D}$ & 0 & $\mathrm{~N} \mathrm{D}$ & 0 \\
\hline $\mathbf{A 1 2}$ & $\mathrm{N} \mathrm{D}$ & 0.1 & $\mathrm{~N} \mathrm{D}$ & 0 \\
\hline $\mathbf{A 1 3}$ & $6.21 \pm 30$ & 0.1 & $\mathbf{0 . 4 4} \pm \mathbf{2 . 1}$ & $\mathbf{0 . 0 0 7}$ \\
\hline $\mathbf{A 1 4}$ & $6.21 \pm 30$ & $\mathbf{0 . 1}$ & & 0 \\
\hline Average & $\mathbf{5 . 3 1} \pm \mathbf{1 8}$ & & 0 & 0 \\
\hline
\end{tabular}




\section{CONCLUSION}

The most important isotope of radon from a health standpoint ${ }^{222} \mathrm{Rn}$ decay products, especially ${ }^{218} \mathrm{Po}$ and

${ }^{214} \mathrm{Po}$, it can have a clear negative impact on lung tissue, leading to lung cancer in many cases. Entry of radon gas In housing usually occurs through cracks, joints, pipe fittings in the walls, and sealants loose or dam on Windows, and so on. Based on RAD -7 portable device, it was measured ${ }^{222} \mathrm{Rn}$ in operational units of the Doura refinery in the indoor range from $6.21 \pm 30 \mathrm{~Bq} / \mathrm{m}^{3}$ to $12.4 \pm 33 \mathrm{~Bq} / \mathrm{m}^{3}$ with an average value of $5.31 \pm 18 \mathrm{~Bq} / \mathrm{m}^{3}$. In open spaces ranging from $6.21 \pm 30 \mathrm{~Bq} / \mathrm{m}^{3}$ to ( $\mathrm{N} \mathrm{D}$ ) with an average value of $0.44 \pm 2.1 \mathrm{~Bq} / \mathrm{m}^{3}$, the results were below the action level recommended by WHO of $100 \mathrm{~Bq} / \mathrm{m}^{3}$. The annual effective dose in air indoor $(0.3) \mathrm{mSv} / \mathrm{y}$, and outdoor $(0.1) \mathrm{mSv} / \mathrm{y}$. These results are much less than acceptable results. On the basis of the current results, it can be concluded that the radon levels in indoor and outdoor within acceptable values in the operational units of the Doura refinery.

\section{REFERENCES}

[1] F. Steinhäusler, W. Hofmann, E. Pohl, Local and Temporal Distribution Pattern of Radon and Daughters in Anurban Environment and Determination of Organ-Dose Frequency Distributions with Demoscopical Methods. In: Gesell, T.F. and Lowder, W.M., Eds (1980).

[2] M. Sohrabi, A.R and Solaymanian, Indoor Radon Level Measurements in Iran Using AEOI Passive Dosimeters. Proceedings of the 7th International Congress of the International Radiation Protection Association, 1, Pergamon

Press, Sydney, 242-245 (1988) .

[3] H. Surbeck, and H. Völkle, Radon in Switzerland. International Symposium on Radon and Radon Reduction Technology, 3, VI-3(1991) .

[4] A.S. Alghamdi, and K.A. Aleissa, Influences on Indoor Radon Concentrations in Riyadh, Saudi Arabia (2014).

[5] United Nations Scientific Committee on the Effects of Atomic Radiation Annex B. UNSCEAR Report to the General Assembly. 1, UN, New York (2000) .

[6] UNSCEAR: United Nations Scientific Committee on the Effects of Atomic Radiation. Source and effects of ionizing radiation, United Nations, New York (2000).

[7] S.Lorenz, T. Kaudse, and W. Aeschbach-Hertig, F50/51 Limnophysics Version (2011).

[8] EPA.US Environmental Protection Agency. Technical Support Document, Citizen's Guide to Radon . Washington DC; EPA 400-R-92-011 (1992). 